
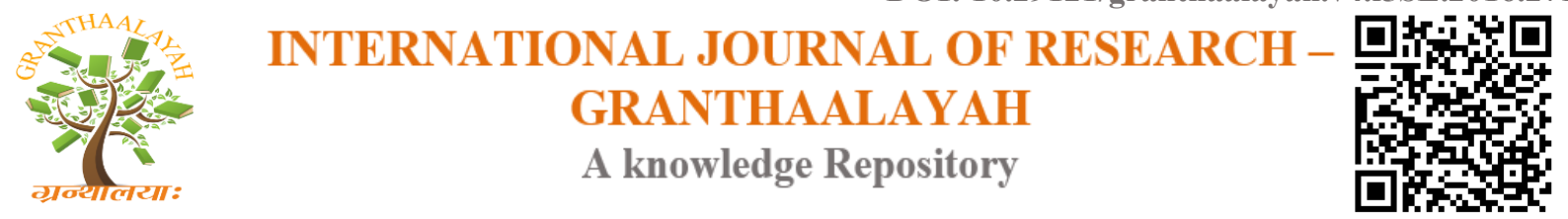

Management

\title{
COMMERCIAL SYSTEM WITH SPECIAL REFERENCE TO E-COMMERCE, ITS PROS \& CONS
}

\author{
Shyju C.M ${ }^{* 1}$
}

${ }^{*}$ Alumni, Department of Commerce, M.S.M College, Kayamkulam, INDIA

\begin{abstract}
E-commerce or Electronic commerce is a methodology of modern business, which addresses the requirements of business organizations. It can be broadly defined as the process of buying or selling of goods or services using an Electronic Medium such as the Internet. A person sitting on his chair in front of a computer can access all the facilities of the internet to buy or sell the products. Traditional commerce that is carried out physically with effort of a person to go and get products. E-commerce has made it easier for human to reduce physical work and to save a lot of time. Even though it gives a lot of advantages to the economy, it faces some demerits mainly in the case of security. Security is the challenge facing E-commerce today. With the invention of E-commerce there is the possibility for $B$ to $B$ business, business through ads in YouTube, through website, mobile commerce, Electronic Fund Transfer, supply chain management, internet marketing, online transaction process etc.. Even though with merits and demerits, E-commerce is in a developing stage.
\end{abstract}

Keywords:

E-commerce, B to B, internet, You tube, Electronic Fund Transfer.

Cite This Article: Shyju C.M, "COMMERCIAL SYSTEM WITH SPECIAL REFERENCE TO E-COMMERCE, ITS PROS \& CONS" International Journal of Research - Granthaalayah, Vol. 4, No. 5: SE (2016): 27-30.

\section{INTRODUCTION}

Electronic Commerce is defined as the process of buying or selling of goods or services using an electronic medium such as the internet.

Electronic Commerce emerged in the early $1990 \mathrm{~s}$ and its use has increased at a rapid rate. ECommerce involves conducting business using modern communication instrument like Internet, Fax, Telephone, E-data inter change, E-Payment, Money transfer system. E-Commerce provides multiple benefits to the consumers in the form of availability of goods at lower cost, wider choice and saves time. People or consumer can buy goods with a click of mouse button without moving out of their house or offices. Similarly, online services such as Internet banking, Tickets include Airlines, Railway, Bus Bill Payment, Hotel Booking etc.... 


\section{OBJECTIVES}

- The primary objective of the study is to analyse E-Commerce and traditional Business.

- To present an overview of the benefits and problems of E-Commerce

\section{METHODOLOGY}

This article is depending upon primary data and secondary data. I have collected primary data from the B.Com II year students of M.S.M College, Kayamkulam. Case study method, interview and observation techniques are mainly used for collecting primary data. The secondary data mainly collected from various statistics data bases of authenticated official sites, journals and websites.

\section{E-COMMERCE}

E-Commerce proved its importance based on the fact where time is essence. In the commercial markets, time plays an important role to both the business and consumers. From the business perspective, with less time spent during each transaction, more transaction can be achieved on the same day. As for the consumer, they will save up more time during their transaction. For instance, a banking transaction can be completed through the internet within a few minutes compared to the traditional banking method which may take up to hours.

\section{CASE STUDIES}

When we first started building websites to try to earn additional side income to other than corporate jobs, we always found it inspiring and encouraging to read e-commerce examples and case studies.

Two case studies are given to the students for discussion to extract an idea about Ecommerce, Traditional commerce, its merits and demerits.

\section{Case STUDY: (1)}

How a fresh juice company grew sales from Rs 10,000 per month to Rs 86000 per month.

Alexander the founder of Raw generation, similar to all business, went through a phase of figuring out how to generate sales.

He had to figure out how to position her juicing product, and what is the most effective way to generate more sales. He experienced with deal sites (such as Groupon etc...) and grew her business from there.

Case STUDY: (2)

How a Business Built a 5 Figure Business Leveraging off YouTube? 
Most people believe that the only way to market to potential buyers is through traditional advertisement channels, such as newspaper or magazine ads.

What this man did, was tap into You Tube- one of the fastest and most popular channels to sell this products. This 'free' way of marketing is extremely powerful and effective. Tutorials are in excellent way of building a brand, fan base, and eventually marketing helpful products for your audience to purchase to them accomplish their goals.

From this study the following points are generated.

\section{TRADITIONAL COMMERCE V/S E-COMMERCE}

Going through these case studies the students reveled the following points in connection with traditional commerce and E-commerce.

\section{TRADITIONAL COMMERCE E-COMMERCE}

\begin{tabular}{|l|l|}
\hline $\begin{array}{l}\text { Communication of business depends upon } \\
\text { individual skills intervention. }\end{array}$ & In E-commerce, there is no human. \\
\hline $\begin{array}{l}\text { Heavy dependency on information ex-change } \\
\text { from person to person communication } \\
\text { channels. }\end{array}$ & Information sharing is made easy via electronic \\
\hline $\begin{array}{l}\text { No uniform strategy can be easily established } \\
\text { and maintained and maintained in E- } \\
\text { commerce. }\end{array}$ & A uniform strategy can be easily established. \\
\hline $\begin{array}{l}\text { Unavailability of a uniform Platform, as } \\
\text { traditional commerce depends heavily on } \\
\text { personal communication. }\end{array}$ & $\begin{array}{l}\text { E-commerce websites provides the user a } \\
\text { platform where all the information is available } \\
\text { at one place. }\end{array}$ \\
\hline
\end{tabular}

\section{ADVANTAGES \& DISADVANTAGES OF E-COMMERCE}

E-commerce offered many advantages to companies and customers but it also caused many problems.

\section{ADVANTAGES OF E-COMMERCE}

- Faster buying / selling procedure, as well as easy to find products

- Buying / selling -24/7

- More reach to customers, there is no theoretical, geographic limitations.

- Low operational cost and better quality of services

- No need of physical company setup.

- Easy to start and manage business

- Customers can easily select products from different providers without moving around physically. 


\section{DIS ADVANTAGES OF E-COMMERCE}

- Any one, good or bad can easily start a business. And there are many bad sites which eat up customer's money.

- There is no guarantee of product quality.

- Mechanical failures can cause unpredictable effects on the total processes.

- As there is minimum chance of direct customer company interactions, customer loyalty is always on a check

- There are many hackers who look for opportunities, and thus an e-commerce site, service, payment gateways; all are always prone to attack.

\section{CONCLUSION}

The invention of faster internet connectivity and powerful online tools has resulted in a new commerce arena- E-commerce. For both consumers and business, E-commerce proves to be more convenient as online trading has less red tape compared to traditional commerce method in global market sense, the appearance of E-commerce as a pioneer has opened up various windows of opportunities for a variety of other companies investors. In short a variety of new markets have emerged from E-commerce itself giving a boost to the global market. In short, if without any major obstacles, E-commerce will certainly continue to mature in the global market and eventually, it will become an essential business plan for a company in order to survive and stay competitive in the ever changing market.

\section{REFERENCES}

[1] Electronic Commerce :- A manager's guide, kalakota et al, Addison Wesley

[2] Internet commerce: - Digital models for Business, Lawrence et al, Addison-Wesley.

[3] "Economics Focus" - The click and the dead.

[4] "Rappa, P-Business Models on the web" :-

[5] Net impact, Mission Statement, Electronic Document

[6] 'On line shopping' :- "The prisoner who pioneered a home shopping revolution"- BBC News 